\title{
Communication System of Documentation of the Legal Sphere: The Concept and Place Among Documentation Systems
}

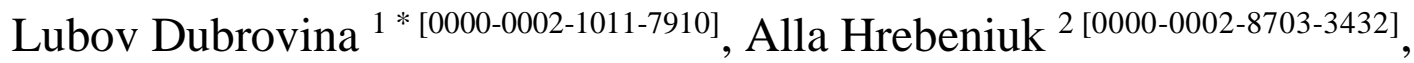 \\ Iryna Manzhul 2 [0000-0002-6507-871X] \\ ${ }^{1}$ National Library of Ukraine named after V.I. Vernadsky, Kyiv, Ukraine \\ ${ }^{2}$ National Academy of Security Service of Ukraine, Kyiv, Ukraine \\ *dubrovina@nbuv.gov.ua
}

\begin{abstract}
In the conditions of formation of documentation systems of Ukraine, being integrated into world similar systems, the development of branch documentary mechanisms, their integration among themselves at the national and international level becomes relevant. Of particular importance among such mechanisms is the system of legal documentation and its subordinated communication system of documentation of the legal sphere. The question of formulating the concept for the latter and clarifying its relationship with other known documentation systems is in demand. Current legislation, available scientific and lexicographical works do not provide an unambiguous answer to this question. Therefore, there is the necessity of: specialized study and generalization of all sources related to this issue; critical rethinking of the provisions developed by practitioners and scholars in this field; making of an unambiguous position on correlation of terms of communication system of documentation support of legal sphere, disciplinary, basic and infrastructural systems of documentation. Arguments in favor of distinguishing these documentary phenomena and their relationship, taking into account vertical (hierarchical) and horizontal connections, were formulated. The results of the study made it possible to: develop an author's definition of the communication system of documentation support of the legal sphere; to determine the regularity of its subordination to the following systems: the system of legal documentation - the public disciplinary (branch) system of documentation - the general system of documentation; to prove its formation as a result of a combination of practical, educational and scientific "basic" areas of law, as well as functional (infrastructural) documentation systems, which are diffuse in nature: regulatory, managerial and organizational-administrative.
\end{abstract}

Keywords: communication system of documentation support of legal sphere, documentation systems, basic documentation systems, disciplinary documentation systems, infrastructure documentation systems, correlation of documentation systems

\section{INTRODUCTION}

The development of document science as well as an academic discipline and a field of practice contributes to the progress of communication at the national and international levels, creates additional impetus to interdisciplinary research. The positive effect of this is obvious, and the need to deepen it highlights the need for branch research.

Therefore, it is important for us to study the communication system [1-2] of documentation support of the legal sphere, to formulate its concept (definition) and to determine its place among the known documentation systems.

\section{RESEARCH METHODOLOGY}

During the work on the subject of our research, the following methods came in handy:

- induction and deduction - to compare individual concepts (communication system of the legal sphere, documentation of the legal sphere, communication system of documentation of the legal sphere, basic, disciplinary and infrastructural systems of documentation);

- analysis and synthesis - in order to determine the category of communication system of documentation of 
the legal sphere, to clarify its place among the documentation systems;

- comparative studies - to study the state of enshrining of the phenomena we study in various regulations and scientific works;

- interpretation - for study of terms developed by other scholars and enshrined in the regulatory framework;

- logical-semantic - to develop new definitions required by documentary practice, clarification of the existing conceptual apparatus;

- structural-functional method - is one of the main in the systematic study of social phenomena and processes; is to divide a complex object into components, study the relationships between them and determine the place and role of all components in the functioning of the object as a whole.

\section{RESULTS OF THE RESEARCH}

Ukrainian and foreign scholars do not question the existence of such an important phenomenon for jurisprudence and social sciences in general as legal documentation. V. Beschastny, O. Merdova, I. Tetarchuk, T. Dyakiv localized it at the level of the educational process, set out the provisions about it in a number of educational publications, which indicates the existence of the theory of scientific knowledge in this area [3-4]. Eight publications in this area were developed by N. Kushnarenko [5].

However, these and other scholars, unfortunately, did not allocate the communication system of documentation support of the legal sphere, which did not help to formulate its definition and to determine its place among the documentation systems.

In some way M. Ilyushenko, T. Kuznetsova and J. Livshits, who considered the essence and correlation of the document and documentation systems, approached to the solution of this problem [6]. But, giving the choice to another subject of their research, they bypassed the question of the existence of a communication system of legal documentation.

The works of G. Shvetsova-Vodka, who studied the functions and qualities of the document in the system of social communications [7], the structure of document science and its place among related scientific disciplines [8], are important for our scientific research. This scientist laid a valuable basis for our study.

However, none of the well-known authors has clearly distinguished the concepts, the consideration of which is the subject of our publication, which does not allow to distinguish them and determine the levels of their ratio. Therefore, in this publication we analyze both legal acts and scientific and lexicographic sources, which made it possible to clarify the essence and place of the communication system of documentation support of the legal sphere among the documentation systems.

\section{DISCUSSION OF RESULTS}

In our previous publications we found that:

communication system of the legal sphere is a form of organization of legal entities that interact by exchanging legal information through scientific, officialbusiness, journalistic, epistolary functional-stylistic mechanisms and communicative qualities of correctness, clarity, accuracy, brevity, expediency, logic, purity, conciseness, in which the documentary aspect plays a decisive role;

documentation support of the legal sphere is a process of creating appropriate conditions for documenting information of a legal nature and organization of office work, necessary for the interaction of participants in the communication system of legal entities, as well as the emergence, change or termination of legal relations.

Taking into account these two definitions, we can formulate the concept of communication system for documentation support of the legal sphere, but, above all, it is necessary to highlight its features. These include:

belonging to the forms of organization of legal entities (organizational aspect);

feasibility through interaction by exchanging legal information (communication aspect);

application of scientific, official-business, journalistic, epistolary functional-stylistic mechanisms (functional aspect);

uniqueness of the combination due to the connection with the legal sphere of communicative and documentary processes: formation in the process of interaction of subjects of law of conditions for creation of legal documents and organization of work with them, which in turn initiate the development of legal relations;

cyclicity and continuity of communicative and documentary processes, their diffusion (interpenetration), which determines the relationship of interdependence between them.

Thus, the communication system of documentation support of the legal sphere (hereinafter - CSDSLS) - is a form of organization, consisting of interdependent communicative and documentary processes, of subjects of law that interact by exchanging legal information provided in the process of documenting (creation of legal documents) and the organization of office work, which leads to the emergence, change or termination of legal relations.

Taking into account this definition and the fact that the system is an order due to the correct, orderly located and interconnected of parts of something [9, p. 1320], we allocate within CSDSLS: a subject component - subjects 
of law, a subject component - legal documents, activity component - an exchange of the legal information shaped in the form of these documents.

At the same time, in the works on document science we meet various definitions of documentation systems, which seem to be related to this definition. Considering them, we propose to find a CSDSLS place among them.

Thus, according to the provisions of the DictionaryHandbook of Terms and Concepts "Documentation", the documentation system is a set of interconnected official documents used in a particular field of activity or industry [10, p. 185]. So, the system of documentation refers to CSDSLS as a generic phenomenon to the species, more to less, more general to less general.

In particular, highlighting the subject component, we note that the documentation system includes all documents, not just legal ones. We find out that R. Katsavets distinguishes between them also documents of economic significance in addition to legal documents, [11]. K. Kislyuk allocates organizationaladministrative, organizational-legal and referenceinformation documentation [12].

Within this system, we are also talking about the activity component - the use of documents, covering the use of something in general, the introduction into use, adaptation to something [10, p. 425], and not purely about the communication manifestation - the exchange of documents. In some way definition of the documentation system clarifies the components of the application of documents. It is which enshrined in paragraph 3.17 of DSTU 4423-1: 2005 "Management of documentation processes" and means an information system that contains service documents, manages documentation processes and provides access to service documents over time [13]. That is, as we can see, within the documentation system we are talking about accumulative, managerial and permitting documentation activities in general, among which the exchange of documents is one of the segments of this whole process.

G. Shvetsova-Vodka also identifies basic documentation systems - documentation systems formed as a result of the functioning of "basic" spheres of social activity (economy, production, science, education, etc.) and / or aimed at ensuring such functioning [10, p. 23].

The author of this definition identifies the scientific and educational spheres as basic, being the part of any activity or ranch. According to the Law of Ukraine "On Scientific and Scientific-Technical Activity": scientific activity is an intellectual creative activity aimed at obtaining new knowledge and (or) finding ways to apply it, the main types of which are basic and applied research; scientific and technical activity is a scientific activity aimed at obtaining and using new knowledge to solve technological, engineering, economic, social and humanitarian problems, the main types of which are applied research and scientific and technical (experimental) developments [14]. In turn, educational activity is the activity of the subject of educational activity aimed at the organization, provision and implementation of the educational process in formal and / or non-formal education [15].

However, we find that economics appears as a social science that studies the production, distribution and consumption of material goods [16], and, therefore, is a part of scientific activity, and therefore does not require separation. At the same time, according to the National Classificatory of Ukraine "Classification of economic activities" DK 009: 2005, adopted by the order of Derzhspozhyvstandart of Ukraine dated December 26, 2005 N 375, economic activity is a process of production (goods and services), which is carried out using certain resources: raw materials, equipment, labor, technological processes, etc. [17]. That is, the definition of economics is also revealed by the term "production" (they are interrelated phenomena) and lies in the plane of practical activity.

Confusion of disparate phenomena occurs in the Dictionary-Handbook of Terms and Concepts "Documentation" in the formulation of a block of basic systems of documentation, which includes: scientific and educational, along with production-operational and economic, socio-political, judicial and legislative, military-defense, internal affairs of the country, civil registration, health care system $[10$, p. 23]. Thus, on the one hand, educational and scientific systems are distinguished, which are basic according to the first definition, and, on the other hand, all other systems contain them (formed on their basis).

We also establish that in this lexicographic source there are allocated only: scientific system of documentation - a basic system of documentation having such subsystems of documentation: scientificorganizational, research, patent, research-technological, research-design [10, p. 133]; educational system of documentation - the basic system of documentation, which has the following subsystems of documentation: educational-organizational, educational-research, educational-control [10, p.129].

We agree that they are really basic, because they form the basis for any of the activities listed above (legislative, military-defense, etc.), for which, at the same time, no definitions are given in the Dictionary-Handbook of Terms and Concepts "Documentation" as for basic documentation systems. At the same time, we consider it necessary to mention practical activities among them. This is the triad that should be attributed to the basic spheres of social activity.

At the same time, we propose to classify the production-operational and economic, socio-political, judicial and legislative, military-defense, internal affairs 
bodies, civil-registration, and healthcare systems as branches and sub-branches, or types and subtypes of activity. Note that there are judicial and legislative subsectors, which are related to the legal sphere, among them. That is, G. Shvetsova-Vodka actually figures it, although she does not clearly outline its place, does not correlate it with documentation systems.

Note that V. Pivovarov, O. Yerakhtorina, O. Lysenko, O. Prudnikova, L. Sidak, O. Shumeiko distinguish legal sciences (one of the basic systems), including applied (criminology, legal psychology, forensic medicine) and theoretical (theory of state and law, history of political and legal doctrines). They distinguish legislative, law enforcement, thus outline a practical basic system and, speaking about the training of a specialist in law, the formation of his competencies, outline the educational system [18].

Thus, the system of legal documentation is a kind of system of documentation formed as a result of the functioning of practical, educational and scientific "basic" areas of law.

However, what is the place in this system for CSDSLS?

It must be said that disciplinary (sectoral) systems of documentation (systems of documentation that are formed as a result of the functioning of various spheres of social activity and according to the content corresponds to a certain scientific field of knowledge, reflect its specifics) are separately distinguished [10, p. 50]. In this case, we record only the scientific component in the absence of educational and practical segments and consider it necessary to allocate them as well (... according to content correspond to a particular scientific field of knowledge, academic discipline and practice in these areas...).

This definition is general and does not define the place of the CSDSLS. We find out that G. ShvetsovaVodka distinguishes three cycles of systems of disciplinary (branch) documentation or types of these systems $[10$, p. 50]:

technical - disciplinary (sectoral) system of documentation, which has the following subsystems: construction, transport, energy, housing and communal, machine-building, agricultural, communication system, aerospace, etc. [10, p. 199];

humanitarian - disciplinary (sectoral) system of documentation, which has the following subsystems: sociological, ethnographic, ecological, archaeological, etc. $[10$, p. 45$]$;

natural - disciplinary (branch) system of documentation, which has the following subsystems: geological, cartographic, geodetic, hydrological, meteorological, soil science, etc. [10, p.169].
That is, she defines groups of scientific disciplines, but the law can not be localized among them. The fact is that jurisprudence belongs to the category of social sciences, the system of documentation for which is not defined in the list above.

Thus, the system of legal documentation is a subsystem of the social disciplinary (branch) system of documentation, which was formed as a result of the functioning of the legal sphere in the basic scientific, educational and practical types of social activity.

In turn, the communication system of documentation support of the legal sphere, being a subordinate phenomenon in relation to the system of documentation as a whole, is specific to the system of legal documentation (hereinafter - SLD), which takes place between CSDSLS and SLD.

In addition to these basic and disciplinary documentation systems, there are also functional (infrastructural) documentation systems - documentation systems that operate in the infrastructure of each basic area of social activity, that is ensure its existence, and have intersectoral significance: management, regulatory, information.

Having analyzed all types of functional (infrastructural) documentation systems, we undoubtedly refer them to the system of legal documentation:

normative-legal system of documentation - functional (infrastructural) system of documentation, which has the following subsystems of documentation: laws and bylaws, decrees of the President, resolutions of the Verkhovna Rada and the Cabinet of Ministers of Ukraine, orders and directives, decisions and instructions of higher bodies; standards, norms, normative-production and instructional documentation [10, p. 140];

management system of documentation - a functional (infrastructural) system of documentation that ensures the implementation of management functions and has the following subsystems of documentation: organizational and administrative, planning, primary accounting, reporting and statistical, accounting, personnel, etc. There are more than forty functional subsystems of documentation;

organizational and administrative documentation - a subsystem of the management system of documentation, which ensures the implementation of organizational and administrative management functions. Includes organizational (statute, memorandum of association, regulations, rules and instructions), administrative (orders, decisions, orders, instructions, resolutions) and reference and information (statements, reports and explanatory notes, protocols, vacation schedules) documents [10, p. 149].

We consider these types of functional systems of documentation to be diffuse, penetrating into all basic 
and disciplinary systems of documentation, as well as into CSDSLS.

\section{CONCLUSIONS}

Thus, the communication system of documentation support of the legal sphere is a component of the social disciplinary subsystem of legal documentation and a form of organization (consisting of interdependent communicative and documentary processes) of subjects of law interacting by exchanging legal information provided in the process of documenting (creation legal documents) and the organization of work with them within the normative-legal, administrative, organizational-administrative functional systems, which

\section{REFERENCES}

[1] Krishn Kumar Gupt (2018), "A Novel Interactive Communication System Realization through Smart Low Noise Block Downconverter", International Journal of Information Technology and Computer Science, vol. 10, no. 7, pp. 39-52. DOI: $10.5815 / \mathrm{ijitcs} .2018 .07 .05$

[2] Farman Ullah, Nadia N Qadri, Muhammad Asif Zakriyya, Aamir Khan (2013), "Hybrid Communication System Based on OFDM", International Journal of Information Technology and Computer Science, vol. 5, no. 12, pp. 31-38. DOI: 10.5815/ijitcs.2013.12.04

[3] Beschastnyi, V.M. and Merdova, O.M. (2016), Yurydychne dokumentoznavstvo: navchalnyi posibnyk [Legal documentation: a textbook], za zah. red. V.M. Beschastnoho, VD "Dakor", Kyiv, Ukraine.

[4] Yurydychne dokumentoznavstvo: navchalnyi posibnyk [Legal documentation: a textbook] (2021), «Tsentr uchbovoi literatury», Kyiv, Ukraine.

[5] Kushnarenko, N.N. (2008), Dokumentovedenie: uchebnik [document management: a textbook], 8-e izd., ster., Znannia, Kyiv, Ukraine.

[6] Iliushenko, M.P. Kuznetsova, T.V. and Livshits, Ya.Z. (1977), Dokumentovedenie. Dokument $i$ sistemy dokumentatsii [Document management. Document and documentation systems], MHYAY, Moskva, Rossiia.

[7] Shvetsova-Vodka, H.N. Funktsii $i$ svoistva dokumenta $v$ sisteme sotsialnykh kommunykatsiy [Functions and properties of the document in the system of social communications: article], (1994), Knyha: issled. i materialy, sb. 69, ss. 37-57.

[8] Shvetsova-Vodka, H.M. (2004), Struktura dokumentoznavstva i yoho mistse sered sumizhnykh leads to the emergence, change or termination of legal relations.

The place of CSDSLS among documentation systems is defined by:

- its existence under the conditions of hierarchical relations in the following order: CSDSLS - system of legal documentation - public disciplinary (branch) system of documentation - general system of documentation;

- its formation as a result of the functioning of practical, educational and scientific "basic" areas of law;

- its use of functional (infrastructural) documentation systems, which are diffuse in nature: regulatory, managerial and organizational-administrative.

naukovykh dystsyplin [The structure of document science and its place among related scientific disciplines: article], Studii z arkhivnoi spravy ta dokumentoznavstva, t.12, ss. 120-125.

[9] Velykyi tlumachnyi slovnyk suchasnoi ukrainskoi movy [Large explanatory dictionary of the modern Ukrainian language] (2009), uklad. i holov. red. V.T. Busel, VTF "Perun”, Kyiv; Irpin, Ukraine.

[10] Shvetsova-Vodka, H.M. (2011), Dokumentoznavstvo: slovnyk-dovidnyk terminiv $i$ poniat [Documentation: a dictionary-reference book of terms and concepts], Znannia, Kyiv, Ukraine.

[11] Katsavets, R.S. (2020), Dilova ukrainska mova. Za novym Ukrainskym pravopysom. Navchalnyi posibnyk [Business Ukrainian language. According to the new Ukrainian spelling. Tutorial], Alerta, Kyiv, Ukraine.

[12] Kysliuk, K.V. (2011), Spetsialne dokumentoznavstvo. Modulnyi kurs [Special document science. Modular course], Kondor, Kyiv, Ukraine.

[13] DSTU 4423-1:2005, Keruvannia dokumentatsiinymy protsesamy. Ch. 1. Osnovni polozhennia [DSTU 4423-1: 2005. Documentation process management. Part 1. Basic provisions], available at: http://ksv.do.am/GOST/DSTY ALL/DSTU2/dstu_4423-1-2005.pdf

[14] Zakon Ukrainy "Pro naukovu $i$ naukovotekhnichnu diialnist" [Law of Ukraine "On Scientific and Scientific-Technical Activity"], available at: https://zakon.rada.gov.ua/laws/show 1848-19\#Text

[15] Zakon Ukrainy "Pro osvitu” [Law of Ukraine "On Education"], available at: https://zakon.rada.gov.ua /laws/show/2145-19\#Text 
[16] Ekonomika [Economy]. Gemet, available at: https://www.eionet.europa.eu/gemet/uk/concept/2 501

[17] Natsionalnyi klasyfikator Ukrainy "Klasyfikatsiia vydiv ekonomichnoi diialnosti" DK 009:2005, pryiniatyi nakazom Derzhspozhyvstandartu Ukrainy vid 26 hrudnia 2005 r. N 375 [National Classifier of Ukraine "Classification of Economic Activities" DK 009: 2005, adopted by the order of Derzhspozhyvstandart of Ukraine dated December
26, $2005 \quad \mathrm{~N}$ 375], available at: https://ips.ligazakon.net/document/fin19567?an=2 \&ed=0000_00_00

[18] Pyvovarov, V.M. Yerakhtorina, O.M. Lysenko, O.A. Prudnykova, O.V. Sidak, L.M. and Shumeiko, O.A. (2020), Mova ukrainskoi yurysprudentsii: navch. posib [The language of Ukrainian jurisprudence: a textbook], Pravo, Kharkiv, Ukraine. 